\title{
Understanding the Consumption of Television Programming: Development and Validation of a Structural Model for Quality, Satisfaction and Audience Behaviour
}

\author{
Carmen Berné Manero ${ }^{1}$, Esperanza García-Uceda ${ }^{2} \&$ Víctor Orive Serrano ${ }^{1}$ \\ ${ }^{1}$ School of Economics and Business, University of Zaragoza, Zaragoza, Spain \\ ${ }^{2}$ School of Social Sciences and Labour, University of Zaragoza, Zaragoza, Spain \\ Correspondence: Victor Orive Serrano, Department of Marketing Management and Market Research, School of \\ Economics and Business, University of Zaragoza, Zaragoza, Spain. E-mail: orive@unizar.es
}

\author{
Received: November 6, 2012 Accepted: November 28, 2012 Online Published: January 22, 2013 \\ doi:10.5539/ijms.v5n1p142 URL: http://dx.doi.org/10.5539/ijms.v5n1p142
}

\begin{abstract}
Within a nowadays context characterised by an increasing number of television channels and by a widely fragmentation of the audience, the study of television content from the consumer's perspective acquires special interest for managers of television stations.

This paper, given the aforementioned reality, analyses and identifies the relationship structure that underlies the constructs of satisfaction and quality in order to gain a more in-depth understanding of the behaviour of television consumers.

The methodology applied is structural equation models and results clearly show a causal link between the variables and confirm the predictive validity of the proposed model. This work provides a framework of reference for developing a cognitive-affective model for the consumption of television programmes, thereby integrating perceived quality as a cognitive variable and satisfaction as an affective variable.

The results of the work provide a more in-depth understanding of a television consumer's behaviour, and they can therefore help to increase the effectiveness of actions by television advertisers and programmers, thereby allowing television stations to improve their results.
\end{abstract}

Keywords: satisfaction, quality, television program, audience behaviour, structural equation models, scales, consumption of television programs

\section{Introduction}

Television's penetration in homes is nearly $100 \%$, thereby reaching a potential market of the entire population if a broadcast is free-to-air. Television's high presence, with an average of 2 television sets per home, is related to its growing use, to its leadership in allocated advertising budgets (Note 1) and to the continuous changes to which it is currently subject (Note 2). Moreover, viewers' 'no-charge' perception regarding free-to-air television fosters television viewing, which has become one of the top options for covering leisure time (Baraybar, 2006).

Regional television stations are a major source of employment and a driving force of the audio-visual industry in their respective territories (Casado, 2005). However, as a whole these regional stations have an accumulated debt that exceeds 1.48 billion Euros and have poorer audio-visual results with respect to other television stations (Note 3). Aragón Televisión (ATV), the regional television station in the Community of Aragón, had a cost of 41 euros per citizen of Aragon, an accumulated debt of 15 million Euros and a budget of over 50 million Euros (Note 4). In the 5 years that it has been broadcasting, the station's audience share has solidified around 9\%, holding fourth place in the list of the most-viewed broadcasters in Aragón. The entertainment programme "Aragoneses por el mundo" and the news programme "Aragón noticias 1" are noteworthy in ATV's programming schedule due to their good acceptance among the Aragonese public. Conversely, the cultural programme "Borradores" has audience results that are far below the station's average.

Literature on television consumer behaviour has focussed mainly on analysing the influence by socio-demographic variables (Wonneberger et al., 2009), motivational variables (Papacharissiu \& Mendelson, 2007), attitudinal variables (Igartua \& Badillo, 2003), variables related to the development of relationships with 
content (Rusell et al., 2004) and personality characteristics in the consumption of this medium (Lu \& Lo, 2007). However, except for the work by $\mathrm{Lu}$ and Lo (2007), literature has not dealt extensively with the television audience's satisfaction with television programmes from a marketing perspective.

The study of satisfaction as a central element in a consumer's decision has attracted great attention in marketing research (Anderson et al., 1994). Thus, within the context of consumer behaviour, satisfaction is one of the main subjects of study (Oliver, 1980). At a practical level, high consumer satisfaction has considerable benefits for companies, it strengthens the image of companies in their environment and favours disinterest by consumers in the competition's offer (Carvin, 1988).

On the other hand, together with satisfaction, perceptions of quality have been recognised as key constructs for explaining consumer behaviour (Zeithaml et al., 1993). Academic literature on the television medium has shown growing interest in researching the dimensions of the quality of audio-visual content from the viewer's perspective (Shamir, 2007). However, the contributions by literature regarding the dimensions of the quality of television content have not managed to achieve a clear consensus about the nature and measurement of quality in television programmes.

Thus, the study of causal relationships between satisfaction and perceived quality is an extensively debated subject in literature on service marketing (McDougall \& Levesque, 2000). Analysing the relationships between both of these variables allows the consumer's evaluation process to be understood and allows service providers to optimise management efforts regarding their quality and service satisfaction policies (Cronin \& Taylor, 1992). However, within the specific context of a television consumer's behaviour, there is little research to confirm the relationships between satisfaction and perceived quality.

Thus, the main contribution of this work is the proposal and empirical testing of a model that contains the influence by perceived quality and by satisfaction on the consumption of television programmes, specifically the programmes Aragoneses por el mundo, Aragón noticias 1 and Borradores. Moreover, the relationships between these two variables are studied by researching the antecedents and consequences of audience satisfaction and of perceived quality in television programs, and the key dimensions with respect to assessing the level of satisfaction and perceived quality in entertainment, news and cultural programmes are analysed. The results of the work provide a more in-depth understanding of a television consumer's behaviour, and they can therefore help to increase the effectiveness of actions by television advertisers and programmers, thereby allowing television stations to improve their results.

\section{Background}

\subsection{Satisfaction with Television Consumption: Antecedents and Consequences}

Consumer satisfaction is a concept that has been widely debated in literature. A number of definitions have been proposed, yet there still is no consensus (Vanhamme, 2000). This fact has hindered both the development of valid measurements and the comparison and interpretation of empirical results (Giese \& Cote, 2000).

There are numerous and, at the same time, are very different approaches to the concept of consumer satisfaction. Depending on the author, satisfaction is purely emotional (Oliver, 1980) or a cognitive comparison (Giese \& Cote, 2000). The combination of these two approaches reveals that satisfaction with a product or service contains both emotional and cognitive components (Bigné \& Andreu, 2004) and is the result of a comparison between a subjective experience and a prior base of reference. This principle of comparison is established in literature on consumer satisfaction within the paradigm of the disconfirmation of expectations (Oliver, 1980).

There have been numerous contributions by literature regarding the concept of media consumer satisfaction. They haven't always coincided and haven't reached a clear consensus about the nature of satisfaction. Within the context of television, consumer satisfaction is based on the aforesaid paradigm of the disconfirmation of expectations (Palmgreen \& Rayburn, 1985; LaRose \& Atkin, 1988; Perse \& Rubin, 1988; Jacobs, 1995; Lu \& Lo, 2007).

Literature on the behaviour of television consumers has analysed the impact by various motivational, technological, attitudinal and behavioural or performance variables on the formation of satisfaction in the audience, all within different contexts (see Table 1). 
Table 1. Antecedents of satisfaction with television consumption

\begin{tabular}{ll}
\hline Author and study context & Antecedents \\
\hline Palmgreen \&Rayburn (1985) & Motivations/gratifications sought \\
University students & Motivations/gratifications obtained \\
News programmes & Motivations or gratifications sought \\
Perse \& Rubin (1988) & Attitude towards the programme \\
University students & Planning before the programme \\
Television series & Attention during the programme \\
& Parasocial Interaction \\
& Comments and reminder after the programme \\
LaRose \& Atkin (1988) & Attitudinal variables \\
Cable television subscribers & Technological equipment \\
& Demographic variables \\
Perse and Ferguson (1993) & Motivation \\
General television consumption & Technological equipment \\
& Demographic variables \\
Jacobs (1995) & Performance \\
Cable television subscribers & Behaviour \\
& Company \\
Lu \& Lo (2007) & Motivation \\
Drama series & Attitudes \\
& Connectedness \\
Godlewski \& Perse (2010) & Performance \\
Reality Shows & Demographic variables \\
& Motivation \\
& Audience attitude: audience participation, \\
& perception of realism, identification with the \\
characters and post-exposure activities
\end{tabular}

Source: own preparation. Non-significant variables in italics

Thus, considering motivational variables, Palmgreen \& Raybun (1985) identified the gratifications sought and obtained by viewers of news programmes as the main antecedent in the satisfaction of television consumers. Persé \& Rubin (1988) expanded the prior work by Palmgreen and Raybun, thereby including attitudinal and behavioural variables related to the activity of the audience before, during and after exposure to a television series. The results obtained indicated that motivational variables or the gratifications sought were the main predictors of viewer satisfaction. These results are similar to those obtained by subsequent research (Lu y Lo, 2007).

With respect to technological variables, Perse and Ferguson (1993) found that television technologies did not have an influence on increasing satisfaction with television viewing. Conversely, the reasons for watching television and the quantity of time spent watching are antecedents of satisfaction. The research by LaRose and Atkin (1988) in the cable television context also found no influence by technological variables on satisfaction.

Regarding works that study behavioural variables, Lu and Lo (2007) pointed out that, based on the connection that viewers develop with television characters in the television environment, satisfaction with drama series increases significantly. The results obtained indicated the importance of the 'connectedness' construct in the formation of satisfaction with drama television series. In the work by LaRose and Atkin (1988), behavioural variables did not allow predicting the satisfaction of subscribers of a North American cable television company. This result does not coincide with the result obtained in the work by Jacobs (1995).

Finally, the evaluation of performance based on an assessment of the attributes of programmes is considered to be an important predictor of satisfaction with television programmes or with cable television. Lu and Lo (2007) determined that the subject, plot, script, dialogues, casting, visual effects and music of a television series are predictor attributes of satisfaction with a programme.

Most of the reviewed works used the exploratory methodology. More recently, the work by Patwardham et al. (2011) established the importance of developing a measurement scale that might study the relative importance of 
the various dimensions that a media consumer could assess when determining satisfaction. The results obtained in the research by Patwardham et al. (2011) allowed confirming the emotional nature of satisfaction in media consumption and the adaptation thereof to different media formats, genres and content. However, the cognitive origin of satisfaction in media consumption could not be confirmed from a review of literature.

In literature on the media, satisfaction is a widely used construct in studying the effects by media (Patwardham et al., 2011). It is the result of desired consumption (Palmgreen \& Rayburn, 1979) and a likely predictor of future behaviour ( $\mathrm{Lu} \& \mathrm{Lo}, 2007$ ). Yet, the relationship between the intentions derived from the level of satisfaction and the subsequent real behaviours of consumers is not clearly identified in literature. From a review of literature, we would highlight word-of-mouth communication, purchase-repurchase intentions, complaining behaviour and willingness to pay more (Andreu \& Bigné, 2004).

Within the specific context of the behaviour of television consumers, there is little research that has confirmed the consequences of satisfaction (see Table 2). The study by Lu and Lo (2007) clearly showed that satisfaction with drama programmes has a positive influence on word-of-mouth communication, on watching advertising spots while a programme is being broadcast and on the intention to view a programme again. This latter result was also confirmed in the work by Aragón and Llorens (1996) within the context of studying the television programmes regularly watched the most by university students. Conversely, the work by Rhee, Kim and Shim (2009) does not allow confirming that satisfaction has an influence on the value of a television station that broadcasts a programme. Research conducted within the context of pay-per-view programming has studied the influence by economic variables on the formation of satisfaction with the cable television service (Jacobs, 1995). However, from a review of literature on satisfaction in television consumption, no specific works that study the willingness to pay for the consumption of free-to-air programmes have been found.

Table 2. Consequences of satisfaction with television consumption

\begin{tabular}{ll}
\hline Author and study context & Consequences \\
\hline $\begin{array}{l}\text { Aragón \& Llorens (1996) } \\
\text { Television programmes of different genres }\end{array}$ most & Consumption repetition \\
$\begin{array}{l}\text { regularly watched } \\
\text { Rhee, Kim \& Shim (2009) }\end{array}$ & Value of the television station \\
$\begin{array}{l}\text { Television programmes of different genres } \\
\text { Lu \& Lo (2007) }\end{array}$ & $\begin{array}{l}\text { Consumption repetition } \\
\text { Drama series }\end{array}$ \\
& $\begin{array}{l}\text { Word-of-mouth comments } \\
\end{array}$ \\
\hline
\end{tabular}

So the research conducted on media consumer satisfaction tries to clarify the meaning and the implications of this construct. However, a review of academic contributions indicates that research on satisfaction hasn't been able to establish a consensus about the modelling of the antecedents and consequences of satisfaction in media consumption, specifically television. This fact reinforces the need to delve deeper into the bases of this type of research and achieve a consensus that might be extended to the modelling.

\subsection{Quality in Television Consumption: Antecedents and Consequences}

The perceptions of quality have been recognised as key constructs for explaining consumer behaviour (Parasuraman et al., 1985). In literature on services, perceived service quality is considered to be the difference between the expectations or desires of customers and their perceptions about the results (Zeithaml et al., 1993).

Within the scope of the media, specifically in literature on television, defining quality is a complex subject (Medina, 2006). There have been numerous contributions in literature about the quality of television content, but at the same time they have been very different and haven't succeeded in achieving a clear consensus about the nature of quality in television. From a review of literature, quality has been assessed according to three different and sometimes opposing perspectives: those of television consumers, those of the creators of television products and those of media managers (see Table 3). 
Table 3. Attributes in assessing the quality of television content

\begin{tabular}{lll}
\hline Perspective & Author & Dimension \\
\hline Consumer & Ishikawa (1992) & Adaptation to opinions \\
& Aragón \& Llorens (1996) & Adaptation to interests \\
& Cubeles (2002) & Consideration of viewers' judgements \\
& Del Valle (2005) & Adaptation to demands \\
& Sánchez Tabernero (2006) & Adaptation to needs and demands \\
& Medina (2006) & Adaptation to interests \\
Content creators & Broadcasting Research Unit (1989) & Technical and narrative rigour \\
& Nositer (1995) & Technical excellence \\
& Albers (1996) & Formal elements, content elements, focus, etc. \\
& Aragón \& Llorens (1996) & Tangible elements (decoration, etc.) \\
& Del Valle (2005) & Adequate technical aspects \\
& Mephan (1990) & Truth-telling \\
& Blumler (1991) & Integrity and respect for plurality \\
& Del Valle (2005) & Cost of programmes \\
& Sánchez Tabernero (2006) & Cost of programmes \\
& & Audience data \\
\hline
\end{tabular}

Source: own preparation

Thus, considering the perspective of television consumers, Cubeles (2002) defines quality based on television viewers' opinions about the television programming. Several works consider the suitability of content to a viewer's interests, opinions (Ishikawa, 1992), needs and demands (Sánchez Tabernero, 2006) as dimensions for assessing quality in television programmes.

Considering the creators' perspective, content - the result of combining creativity and technical production - is the central aspect of the quality of a programme (Medina, 2006). The works by the Broadcasting Research Unit (1989), Nositer (1995), Albers (1996), Aragón and Llorens (1996), Del Valle (2005) and Sánchez Tabernero (2006) point out the importance of technical aspects in the configuration of quality in television programmes.

From the perspective of media managers, quality programmes must present certain characteristics, such as respect for plurality and integrity (Blumler, 1991), truth-telling (Mepham, 1990), ingenuity and the absence of coarseness and sensationalism (Sánchez Tabernero, 2006). Other works allude to management and financial aspects, such as audience data and cost per programme production hour (Medina, 2006).

Consequently, the selected studies agree that quality appears to be a multidimensional concept and that it must be assessed according to the various genres of programmes and stations. Moreover, literature provides no clear consensus about the antecedents and consequences of quality in television programmes. These facts reinforce the need to delve deeper into the bases of this type of research and achieve a consensus that can be extended to the modelling.

\subsection{Causal Relationships between Quality and Satisfaction}

The relationship between satisfaction and perceived quality has been an extensively debated subject in literature on service marketing (McDougall \& Levesque, 2000). The interest in and importance of knowing and having a better understanding of the relationship between both concepts have motivated considerable research that has attempted to establish the causal relationships between them. Thus, various authors defend the idea that perceived quality is an antecedent of satisfaction (Cronin \& Taylor, 1992; Anderson et al., 1994). On the other hand, other research has defended the opposite position, thereby considering satisfaction to be an antecedent of perceived quality (Bitner \& Huber, 1994). Other works, such as those by Teas (1993), Berné et al., (1996) and Driver (2002) pose the existence of a two-way relationship between satisfaction and quality.

Furthermore, there is a growing consensus in literature around the proposal that perceived quality is an antecedent of satisfaction (Bloemer et al., 1998). Thus, the assessment of satisfaction requires a specific experience, while perceived quality does not (Berné et al., 1996). Moreover, satisfaction depends on the relationship between perceived quality and the costs incurred in consumption (Dodds et al., 1991), yet perceived 
quality is not necessarily determined by the price of a product. Therefore, according to this approach, quality is an antecedent of satisfaction (Kang \& James, 2004).

Within the specific context of the behaviour of television consumers, there is little research that has confirmed the relationships between satisfaction and perceived quality. The work by Aragón and Llorens (1996) confirmed that the quality of a television programme has a highly significant effect on a television viewer's satisfaction, although the results must be considered with prudence, given the nature of the sample used. The research by Rhee, Kim and Shim (2009) confirmed, within the context of 25 programmes of various genres in a sample of South Korean viewers, that perceived quality is an antecedent of satisfaction in television programmes.

On the other hand, together with satisfaction and the perceptions of quality, the intention to repeat is a central objective in research on consumer behaviour. Thus, research indicates a clear, direct effect by satisfaction on repeat purchase intentions (Choi et al., 2002). Within the specific context of television consumers, the study by $\mathrm{Lu}$ and Lo (2007) clearly showed that satisfaction has a positive influence on the intention to repeat the consumption of a programme. This result is similar to the one obtained in earlier research (Aragón \& Llorens, 1996).

Therefore, the following hypotheses identify the questions, object of study, and they make up a model (see Figure 1) that allows analysing the influence by perceived quality and satisfaction on the consumption of television programmes, as well as the relationships between these two variables. Moreover, we pose a hypothesis that endeavours to include the effects exercised by variables that would allow us to better characterise consumers. Thus, even though the sign of the relationship is not established, it is proposed that sex, age, the province and the area of residence are variables that can have an influence on perceived quality, satisfaction and the intention to repeat regarding a television programme.

Hypothesis 1: The perceived quality of a television programme has a direct and positive effect on a viewer's satisfaction.

Hypothesis 2: A viewer's satisfaction has a direct and positive effect on their intention to repeat.

Hypothesis 3: A viewer's satisfaction has an influence on the effect of the perceived quality of a television programme regarding the viewer's intention to repeat.

Hypothesis 4: The characteristics of viewers, such as sex, age, province and area of residence, can have an influence on their perceptions of quality, their satisfaction levels and their intention to repeat regarding a television programme.

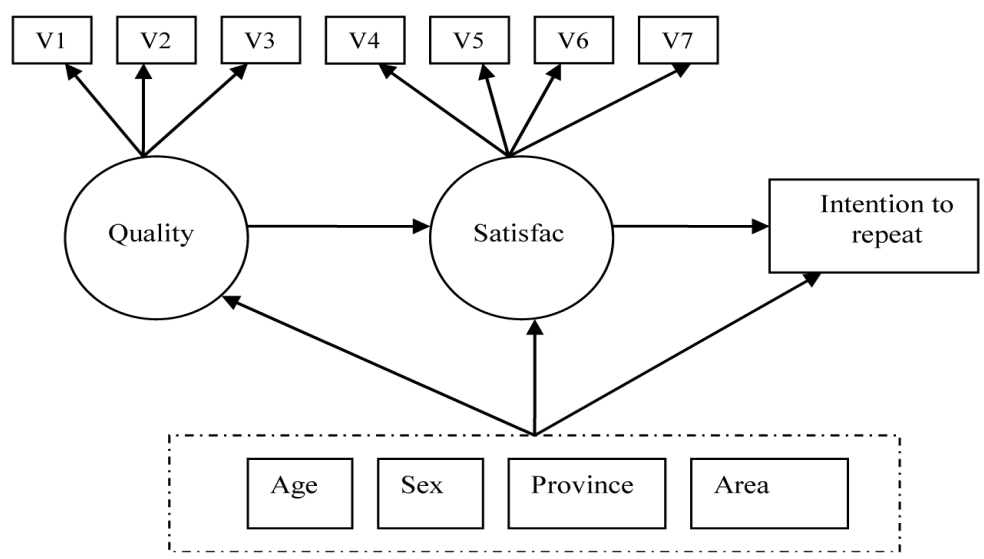

Figure 1. Quality-Satisfaction-Repeat intention model in the consumption of television programmes (CSR-TV)

\section{Analysis Methodology}

\subsection{Data Compilation and Characteristics of the Sample}

The information for the analysis was obtained through a self-administered, ad-hoc survey taken from a sample of 400 individuals during the months of May and June 2011. The valid response rate was $84.5 \%, 73.25 \%$ and $29.75 \%$ for entertainment programmes; news programmes and cultural programmes, respectively (see the data sheet in Table 4). The characteristics of the sample are presented in Table 5. 
Table 4. Technical data sheet of the study

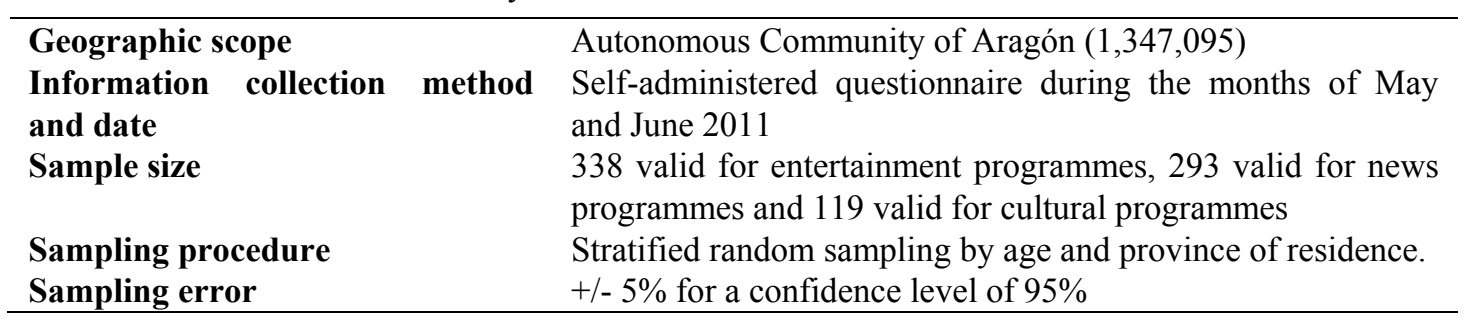

Table 5. Description of the sample

\begin{tabular}{|c|c|c|c|c|c|}
\hline \multicolumn{2}{|c|}{ Entertainment programmes } & \multicolumn{2}{|l|}{ News programmes } & \multicolumn{2}{|c|}{ Cultural programmes } \\
\hline Sex & & Sex & & Sex & \\
\hline Male & $48.5 \%$ & Male & $48.1 \%$ & Male & $46.2 \%$ \\
\hline Female & $51.5 \%$ & Female & $51.9 \%$ & Female & $53.8 \%$ \\
\hline Age & & Age & & Age & \\
\hline From 18 to 25 years & $5.9 \%$ & From 18 to 25 years & $5.5 \%$ & From 18 to 25 years & $7.6 \%$ \\
\hline From 26 to 35 years & $24.9 \%$ & From 26 to 35 years & $24.2 \%$ & From 26 to 35 years & $26.1 \%$ \\
\hline From 36 to 45 years & $25.7 \%$ & From 36 to 45 years & $24.6 \%$ & From 36 to 45 years & $21.8 \%$ \\
\hline From 45 to 54 years & $24.3 \%$ & From 45 to 54 years & $25.9 \%$ & From 45 to 54 years & $26.1 \%$ \\
\hline Over 54 years & $19.2 \%$ & Over 54 years & $19.8 \%$ & Over 54 years & $18.3 \%$ \\
\hline Area of residence & & Area of residence & & Area of residence & \\
\hline Urban areas & $86.1 \%$ & Urban areas & $85 \%$ & Urban areas & $86.6 \%$ \\
\hline Rural areas & $13.9 \%$ & Rural areas & $15 \%$ & Rural areas & $13.4 \%$ \\
\hline \multicolumn{2}{|c|}{ Province of residence } & \multicolumn{2}{|l|}{ Province of residence } & \multicolumn{2}{|l|}{ Province of residence } \\
\hline Huesca & $16.9 \%$ & Huesca & $17.1 \%$ & Huesca & $15.1 \%$ \\
\hline Zaragoza & $68.3 \%$ & Zaragoza & $68.3 \%$ & Zaragoza & $73.9 \%$ \\
\hline Teruel & $14.8 \%$ & Teruel & $14.7 \%$ & Teruel & $10.9 \%$ \\
\hline
\end{tabular}

\subsection{Operationalisation of the Theoretical Concepts}

In order to cover the main objective of this research (analyse the relationships between the variables of quality, satisfaction and intention to repeat), it was essential to follow a rigorous process in developing the measurement scales of the variables. To do so, we first did a comprehensive review of literature on the media, on television consumer behaviour and on marketing. This first stage of the research was directed at determining a relationship between the measurement indicators. Then, in the second stage, the items were screened and the measurement scales were validated for the context of study.

More specifically, for measuring the perceived quality of television programmes, the works by Ishikawa (1992), Aragón and Llorens (1996), Cubeles (2002), Del Valle (2005), Sánchez Tabernero (2006) and Medina (2006) were considered. 3 items were taken from them. For measuring the 'satisfaction' variable, the scale by Patwardhan, Yang and Patwardhan (2011) was used and applied to the television context. This scale is composed of 5 items. For measuring the 'intention to repeat' variable, a single item was used, the one in the study by $\mathrm{Lu}$ and Lo (2007). Regarding the 'willingness to pay' variable, a measurement scale based on the contingent valuation method (CVM) was used, with several possible financial amounts, from 0 to 100 euros. All the indicators were offered in the questionnaire using an 11-point, Likert type measurement scale, from 0 for 'completely disagree' to 10 for 'completely agree'.

Therefore, the items shown in Table 6 represent an adaptation of those provided in specific literature to the specific context of entertainment, news and cultural programmes. 
Table 6. Measurement scales of the variables

\begin{tabular}{ll}
\hline Theoretical concepts & Items \\
\hline PERCEIVED QUALITY & V1: It is a very interesting programme. \\
(Ishikawa, 1992; Aragón \& Llorens, & V2: It is a programme that fits very well with my television \\
1996; Cubeles, 2002; Del Valle, 2005; & tastes. \\
Sánchez Tabernero, 2006; Medina, & V3: It is a very adequate programme for entertaining me \\
2006) & (Note 5). \\
SATISFACTION & V4: After watching the programme, I feel very good. \\
& V5: After watching the programme, I feel very content for \\
having spent time watching it. & V6: After watching the programme, I feel that I have enjoyed \\
(Patwardhan et al., 2011) & it very much. \\
& V7: After watching the programme, I feel that it has been a \\
& very pleasant experience. \\
& V8: I intend to watch the next programme. \\
& V9: To prevent Aragón Televisión from disappearing, how \\
INTENTION TO REPEAT & much money would you be willing to pay each year to \\
(Lu \& Lo, 2007) & continue watching the television station? (the annual cost of \\
WILLINGNESS TO PAY & Aragón Televisión is $€ 41$ per year per resident of Aragón, \\
(CVM) & through taxes) \\
\hline
\end{tabular}

\section{Analysis of the Results}

First of all, we verified the reliability and validity of the scales that were used. Subsequently, the research hypotheses were empirically tested using the structural equation systems method.

\subsection{Reliability and Validity of the Scales}

First the measurement scales used in this research were verified to ensure that they met the psychometric properties. Thus, the scales showed evidence of both content validity, derived from specifying the scales from the domain of the reviewed literature, and reliability, measured based on the Cronbach's alpha indicator, which gives satisfactory values (see Tables 7 and 8 ).

Before analysing the convergent validity, the dimensionality of the measurement instruments was analysed by a principal components exploratory factor analysis of both the perceived quality scale and the satisfaction scale so that an underlying structure in both scales could be obtained, which would allow simplifying the subsequent analysis of the relationships between the variables. It was verified that the dimension considered in the 'perceived quality' variable shows adequate unidimensionality results, as well as the items of the 'satisfaction' variable. Moreover, in all cases the explained variance is significant (over 60\%), and the factor loadings and Cronbach's alphas show values that exceed the recommended minimum (Hair et al., 1999) (see Tables 7 and 8).

To assess the convergent validity of the scales, we resorted to the confirmatory factor analysis, for which EQS 6.1 statistical software was used. Thus, initially a confirmatory factor analysis of the latent variables whose measurement scales were previously described was performed. The factor loadings of the items are significant and exceed 0.60, wherefore they show convergent validity (see Table 9).

After the scales were analysed individually, they were tested together for each type of programme. Thus, the overall fit indexes of the model show values that give it a high value of significance for entertainment programmes and news programmes. However, the root mean square error of approximation (RMSEA) has a value of over 0.1, and the adjusted goodness of fit index (AGFI) has a value that is far below the desirable minimum (Note 6) to be able to confirm predictive validity in the case of cultural programmes (see Table 10). 
Table 7. Results of the exploratory factor analysis of perceived quality in entertainment, news and cultural programmes

\begin{tabular}{llll}
\hline Entertainment programmes (variables) & Factor 1 & Explained variance \% \\
\hline $\begin{array}{l}\text { Aragoneses por el mundo is an interesting } \\
\text { programme (V1) }\end{array}$ & 0.855 & $80.81 \%$ \\
$\begin{array}{l}\text { Aragoneses por el mundo fits my television tastes } \\
\text { very well (V2) }\end{array}$ & 0.872 & \\
$\begin{array}{l}\text { Aragoneses por el mundo is very adequate for } \\
\text { entertaining me (V3) }\end{array}$ & 0.84 & \\
$\begin{array}{l}\text { Cronbach's alpha } \\
\text { News programmes (variables) }\end{array}$ & $\mathbf{0 . 9 2}$ & \\
$\begin{array}{l}\text { Aragón noticias 1 is a very interesting programme } \\
\text { (V1) }\end{array}$ & Factor 1 & Explained variance \% \\
$\begin{array}{l}\text { Aragón noticias 1 fits my television tastes very well } \\
\text { (V2) }\end{array}$ & 0.84 & \\
$\begin{array}{l}\text { Aragón noticias 1 is very adequate for keeping me } \\
\text { informed about what happens in Aragón (V3) }\end{array}$ & 0.88 & \\
$\begin{array}{l}\text { Cronbach's alpha } \\
\text { Cultural programmes }\end{array}$ & $\mathbf{0 . 9 1}$ & \\
Borradores is a very interesting programme (V1) & Factor 1 & Explained variance \% \\
Borradores fits my television tastes very well (V2) & 0.87 & $83.02 \%$ \\
Borradores is very adequate for entertaining me (V3) & 0.82 & \\
Cronbach's alpha & 0.87 & \\
\hline
\end{tabular}

Table 8. Results of the exploratory factor analysis of satisfaction with entertainment, news and cultural programmes

\begin{tabular}{|c|c|c|}
\hline Entertainment programmes (variables) & Factor 1 & Explained variance \% \\
\hline $\begin{array}{l}\text { After watching Aragoneses por el mundo, I feel } \\
\text { very good (V1) }\end{array}$ & 0.84 & $82.21 \%$ \\
\hline $\begin{array}{l}\text { After watching Aragoneses por el mundo, I feel } \\
\text { very content for having spent time watching it (V2) }\end{array}$ & 0.87 & \\
\hline $\begin{array}{l}\text { After watching Aragoneses por el mundo, I feel that } \\
\text { I have enjoyed it very much (V3) }\end{array}$ & 0.86 & \\
\hline $\begin{array}{l}\text { After watching Aragoneses por el mundo, I feel that } \\
\text { it has been a very pleasant experience (V4) }\end{array}$ & 0.85 & \\
\hline Cronbach's alpha & 0.92 & \\
\hline News programmes (variables) & Factor 1 & Explained variance \% \\
\hline $\begin{array}{l}\text { After watching Aragón noticias 1, I feel very good } \\
\text { (V1) }\end{array}$ & 0.85 & $80.37 \%$ \\
\hline $\begin{array}{l}\text { After watching Aragón noticias 1, I feel very } \\
\text { content for having spent time watching it (V2) }\end{array}$ & 0.83 & \\
\hline $\begin{array}{l}\text { After watching Aragón noticias } 1 \text {, I feel that I have } \\
\text { enjoyed it very much (V3) }\end{array}$ & 0.84 & \\
\hline $\begin{array}{l}\text { After watching Aragón noticias } 1 \text {, I feel that it has } \\
\text { been a very pleasant experience (V4) }\end{array}$ & 0.86 & \\
\hline Cronbach's alpha & 0.91 & \\
\hline Cultural programmes & Factor 1 & Explained variance \% \\
\hline After watching Borradores, I feel very good (V1) & 0.87 & $82.91 \%$ \\
\hline $\begin{array}{l}\text { After watching Borradores, I feel very content for } \\
\text { having spent time watching it (V2) }\end{array}$ & 0.86 & \\
\hline $\begin{array}{l}\text { After watching Borradores, I feel that I have } \\
\text { enjoyed it very much (V3) }\end{array}$ & 0.87 & \\
\hline $\begin{array}{l}\text { After watching Borradores, I feel that it has been a } \\
\text { very pleasant experience (V4) }\end{array}$ & 0.84 & \\
\hline Cronbach's alpha & 0.94 & \\
\hline
\end{tabular}


Table 9. Results of the confirmatory factor analysis for entertainment, news and cultural programmes

\begin{tabular}{|c|c|c|c|c|c|c|}
\hline \multicolumn{7}{|c|}{ Entertainment programmes } \\
\hline \multirow{3}{*}{$\begin{array}{l}\text { LATENT } \\
\text { VARIABLE }\end{array}$} & MEASUREM & STANDARDISED & \multirow[t]{10}{*}{$\lambda$} & ROBUST & \multirow{3}{*}{$\begin{array}{l}\text { MEASUR } \\
\text { EMENT } \\
\text { ERROR }\end{array}$} & \multirow[t]{3}{*}{$\mathbf{R}^{2}$} \\
\hline & ENT & COEFFICIENT & & T-VALUE & & \\
\hline & VARIABLE & & & & & \\
\hline F1- $\quad$ PERCEIVED & V1 & 0.916 & & * & 0.40 & 0.84 \\
\hline \multirow{2}{*}{ QUALITY } & $\mathrm{V} 2$ & 0.971 & & 31.18 & 0.23 & 0.94 \\
\hline & $\mathrm{V} 3$ & 0.945 & & 31.05 & 0.32 & 0.89 \\
\hline F2- & V4 & 0.939 & & * & 0.34 & 0.88 \\
\hline \multirow{3}{*}{ SATISFACTION } & V5 & 0.973 & & 46.72 & 0.22 & 0.94 \\
\hline & V6 & 0.964 & & 40.94 & 0.26 & 0.92 \\
\hline & V7 & 0.922 & & 28.06 & 0.38 & 0.84 \\
\hline \multirow{3}{*}{$\begin{array}{l}\text { News programmes } \\
\text { LATENT } \\
\text { VARIABLE }\end{array}$} & & & \multirow{10}{*}{$\lambda$} & & & \\
\hline & MEASUREM & STANDARDISED & & ROBUST & MEASUR & $\mathbf{R}^{2}$ \\
\hline & $\begin{array}{l}\text { ENT } \\
\text { VARIABLE }\end{array}$ & COEFFICIENT & & T-VALUE & $\begin{array}{l}\text { EMENT } \\
\text { ERROR }\end{array}$ & \\
\hline F1- $\quad$ PERCEIVED & V1 & 0.954 & & * & 0.30 & 0.91 \\
\hline \multirow{6}{*}{$\begin{array}{l}\text { QUALITY } \\
\text { F2- } \\
\text { SATISFACTION }\end{array}$} & $\mathrm{V} 2$ & 0.931 & & 33.66 & 0.36 & 0.86 \\
\hline & $\mathrm{V} 3$ & 0.787 & & 17.37 & 0.61 & 0.61 \\
\hline & V4 & 0.936 & & $*$ & 0.35 & 0.87 \\
\hline & V5 & 0.940 & & 30.12 & 0.34 & 0.88 \\
\hline & V6 & 0.929 & & 34.57 & 0.37 & 0.86 \\
\hline & V7 & 0.931 & & 29.58 & 0.36 & 0.86 \\
\hline \multirow{4}{*}{$\begin{array}{l}\text { Cultural programmes } \\
\text { LATENT } \\
\text { VARIABLE }\end{array}$} & & & \multirow{4}{*}{$\lambda$} & & \multirow{4}{*}{$\begin{array}{l}\text { MEASUR } \\
\text { EMENT } \\
\text { ERROR }\end{array}$} & \multirow{3}{*}{$\mathbf{R}^{2}$} \\
\hline & MEASUREM & STANDARDISED & & ROBUST & & \\
\hline & ENT & COEFFICIENT & & T-VALUE & & \\
\hline & $\begin{array}{l}\text { VARIABLE } \\
\text { V1 }\end{array}$ & & & & & 093 \\
\hline \multirow{6}{*}{$\begin{array}{l}\text { QUALITY } \\
\text { F2- } \\
\text { SATISFACTION }\end{array}$} & $\begin{array}{l}\text { V1 } \\
\text { V2 }\end{array}$ & $\begin{array}{l}0.964 \\
0.966\end{array}$ & & * 2808 & $\begin{array}{l}0.26 \\
0.25\end{array}$ & $\begin{array}{l}0.93 \\
0.93\end{array}$ \\
\hline & $\mathrm{V} 3$ & 0.959 & & 22.34 & 0.28 & 0.92 \\
\hline & V4 & 0.979 & & $*$ & 0.20 & 0.95 \\
\hline & V5 & 0.958 & & 20.44 & 0.28 & 0.91 \\
\hline & V6 & 0.969 & & 32.02 & 0.24 & 0.93 \\
\hline & V7 & 0.931 & & 16.25 & 0.36 & 0.86 \\
\hline
\end{tabular}

Table 10. Fit indicators of the model

\begin{tabular}{lcclcccccc}
\hline Estimated model & g.I & p-value & $\begin{array}{l}\chi^{2} \\
\text { (S-B) }\end{array}$ & GFI & AGFI & $\begin{array}{l}\text { BB } \\
\text { NFI }\end{array}$ & $\begin{array}{l}\text { BB } \\
\text { NNFI }\end{array}$ & R-CFI & RMSEA \\
\hline $\begin{array}{l}\text { Entertainment } \\
\text { programmes }\end{array}$ & 34 & 0.0000 & 91.4275 & 0.922 & 0.874 & 0.964 & 0.969 & 0.972 & 0.073 \\
$\begin{array}{l}\text { News programmes } \\
\begin{array}{l}\text { Cultural } \\
\text { programmes }\end{array}\end{array}$ & 63 & 0.0000 & 195.364 & 0.874 & 0.848 & 0.905 & 0.916 & 0.933 & 0.080 \\
\hline
\end{tabular}

\subsection{Test of the Research Hypotheses}

After ensuring the reliability and validity of the scales used, and after having verified that the fit of the model for entertainment programmes and news programmes was adequate, the models were interpreted and the proposed hypotheses were tested. The results finally obtained are shown in Figures 2 and 3.

As it can be observed, the two models show a good fit, and the predictive validity of the proposed model can be confirmed. $66 \%$ and $55 \%$ of a consumer's intentions to repeat in entertainment programmes and news programmes, respectively, are explained by the viewer's perceptions of quality and satisfaction.

Regarding entertainment programmes, the analysis of the model's hypotheses shows significant relationship values for the four posed hypotheses. Thus, Hypothesis 1, which measures the relationship between perceived quality and satisfaction, and therefore the cognitive origin of satisfaction in the consumption of television programmes, is significant $(\mathrm{p}<0.05, \beta=0.931)$. Therefore, Hypothesis 1 is confirmed. In turn, satisfaction exercises a positive effect on the intention to repeat ( $<<0.05, \beta=0.942)$, which confirms the direct effects of satisfaction on behaviour intentions. Therefore, Hypothesis 2 is confirmed. Likewise, satisfaction in the consumption of programmes plays a fundamental role as a consequence of perceived quality $(\mathrm{p}<0.05, \beta=$ $0.931)$ and as an antecedent of behaviour intentions $(\mathrm{p}<0.05, \beta=0.942)$, which allows Hypothesis 3 to be 
accepted. Regarding the sociodemographic characteristics established in Hypothesis 4, it can be observed that the age and province variables have an influence on the 'satisfaction' and 'intention to repeat' variables, respectively. Thus, older viewers are those who perceive less satisfaction with entertainment programmes. On the other hand, it can be observed that only the people who reside in the province of Zaragoza show a greater intention to repeat with respect to residents in the other two provinces of Aragón.

Regarding news programmes, the four hypotheses of the model can be accepted. Regarding the effects of perceived quality, it has a significant effect on satisfaction $(\mathrm{p}<0.05, \beta=0.798)$, which confirms Hypothesis 1 . In turn, the direct and positive influence by satisfaction on the intention to repeat is confirmed $(\mathrm{p}<0.05, \beta=$ 0.894), which allows Hypothesis 2 to be accepted. Likewise, satisfaction in the consumption of programmes plays a fundamental role as a consequence of perceived quality $(\mathrm{p}<0.05, \beta=0.798)$ and as an antecedent of behaviour intentions $(\mathrm{p}<0.05, \beta=0.894)$, which confirms Hypothesis 3 . Regarding the sociodemographic characteristics established in Hypothesis 4, it can be observed that the 'age' variable has an influence on the 'satisfaction' and 'intention to repeat' variables and that the 'province' and 'area of residence' variables have an influence on the 'intention to repeat' variable. Thus, viewers in the age segment from 26 to 35 years perceive less satisfaction with news programmes. On the other hand, it is observed that only consumers who are over 55 years of age show a greater intention to repeat. It can also be observed that inhabitants in the province of Zaragoza show a greater intention to repeat with respect to people who live in the other two provinces of Aragón. The people who reside in urban areas (cities with more than 10000 inhabitants) show a lower intention to repeat regarding news programmes than those who reside in rural areas.

Moreover, it could be confirmed that willingness to pay has a negative moderating effect on satisfaction and on the intention to repeat of viewers of news programmes. Thus, as the satisfaction of a viewer who is willing to pay for consumption increases, their intention to repeat with respect to a programme decreases $(\mathrm{p}<0.05, \beta=$ $-0.059)$. A consumer is not willing to pay for consuming news even though he may be satisfied and may intend to watch the next programme.

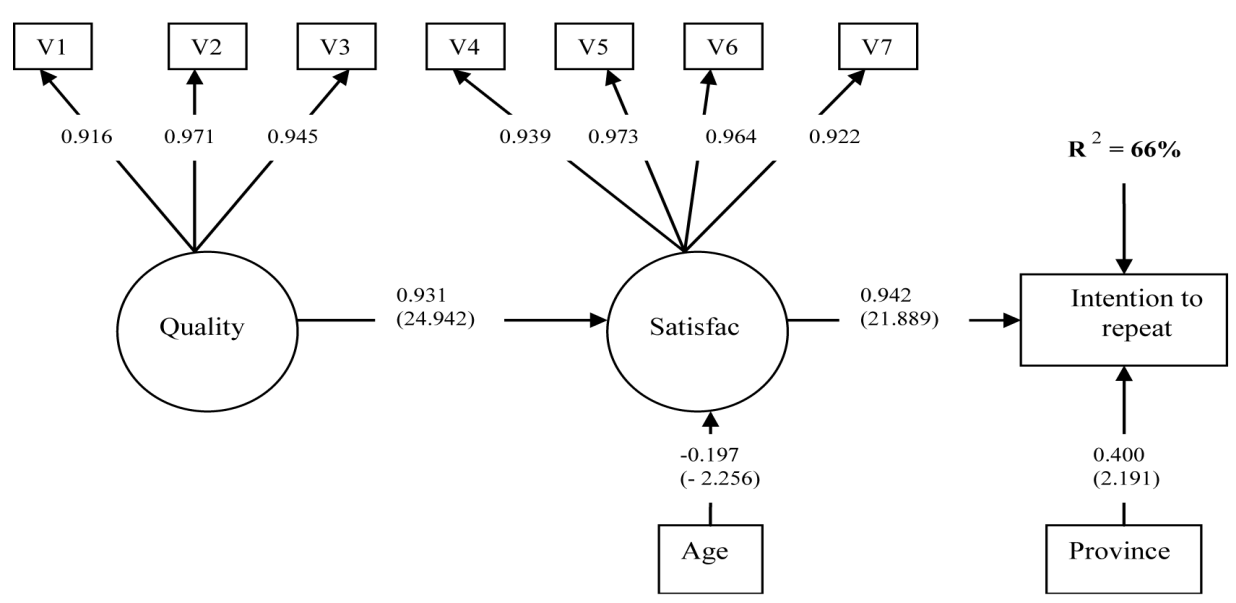

Figure 2. Final CSR-TV model for entertainment programmes 


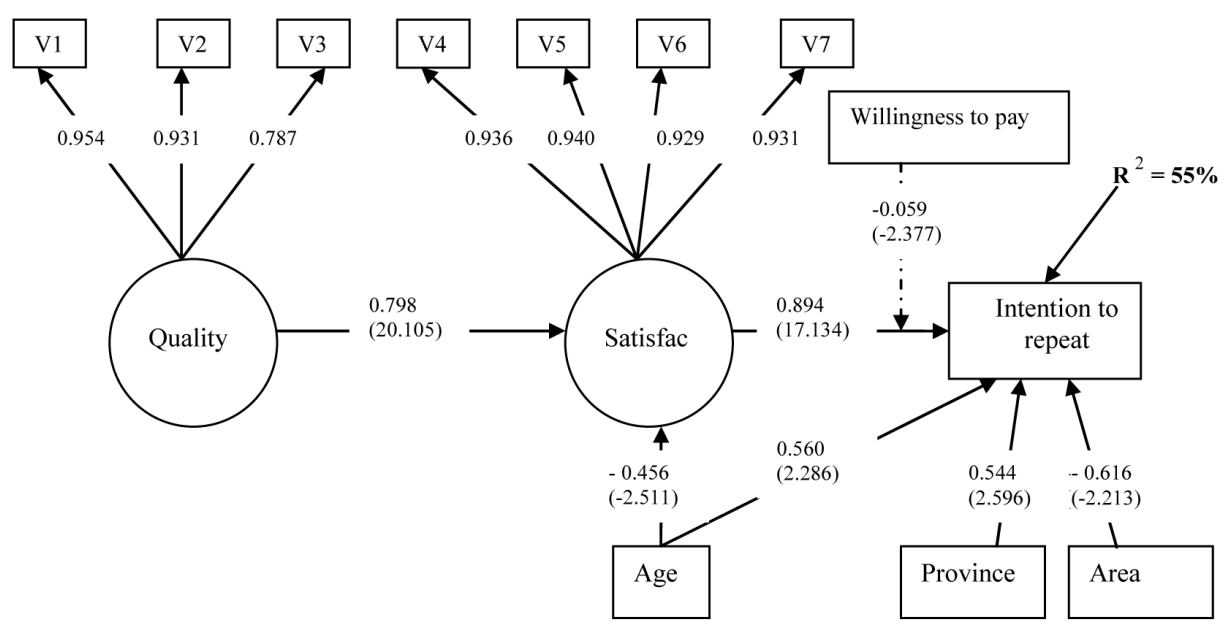

Figure 3. Final CSR-TV model for news programmes

\section{Conclusions, Limitations and Implications for Management}

This work proposes an integrating model for analysing the behaviour of television consumers from a marketing perspective. Thus, the proposed model analyses and identifies the relationship structure between the variables of satisfaction and quality in order to obtain a more in-depth understanding of the behaviour of television viewers.

Within the television context, a review of academic contributions indicates that research has not been able to establish a consensus for modelling the antecedents and consequences of the variables, 'satisfaction' and 'quality'. The importance of developing a model for the consumption of television programmes, thereby integrating the antecedents and consequences of quality and satisfaction, is that it would contribute to clarifying the theoretical nature of the variables and would allow resolving the academic discussions about an adequate measurement of those variables within the context of television programmes.

In view of this situation, this work provides a framework of reference for developing a cognitive-affective model for the consumption of television programmes, thereby integrating perceived quality as a cognitive variable and satisfaction as an affective variable.

The results of the work, first of all, allow confirming a scale for measuring the quality perceived by consumers of entertainment, news and cultural programmes, thereby identifying three key aspects in the assessment of quality: interest in the programme, the suitability of the programme to the viewer's tastes and utility.

Second, the results obtained allow, based on an adaptation of the scale developed by Patwardham et al., (2011), confirming the affective nature of satisfaction in the consumption of entertainment, news and cultural programmes.

Third, and consistent with some earlier works within the scope of marketing, the results of the research clearly show the causality between quality, satisfaction and behaviour intentions. Thus, a consumer's intentions to repeat regarding entertainment programmes and news programmes, respectively, are explained by a viewer's perceptions of quality and satisfaction.

In view of this situation, audio-visual companies, in order to improve their results, should focus their marketing efforts on those aspects that are truly valued by viewers. Thus, based on studying viewers' perceptions of quality and satisfaction, audio-visual managers can improve the acceptance of programmes by the public and thereby improve the results of television stations.

Specifically, the results obtained in the empirical research are highly relevant to decision-making. The perceptions of quality and satisfaction for the entertainment programme, Aragoneses por el mundo, and for the news programme, Aragón Noticias 1, explain $66 \%$ and 55\% of the viewers' intentions to repeat, respectively. So in order to successfully retain viewers, it seems advisable to pay attention to cognitive and affective aspects in the assessments made by consumers. Therefore the capacity of a programme to be interesting, to suit the audience's taste, to entertain or to inform viewers and to appeal positively to the audience's emotions while watching a programme constitutes a valuable tool for adapting a programme to viewers' demands. 
On the other hand, the results of the research clearly show a viewer's negative willingness to pay for watching specific programmes that are broadcast on the programming schedule of a free-to-air station. Thus, even though viewers may be satisfied and may intend on watching the next programme, they will not consider the payment option. This formula for earning revenue for stations does not seem to be viable within our context of study.

Finally, the results obtained have not allowed confirming the predictive validity of the model for cultural programmes. The low response rate of the questionnaire for the programme Borradores, derived from poor knowledge of the same by the viewers and its scarce success among the audience, could be the main cause of this result.

However, certain limitations should be considered, meaning that the results must be regarded with caution. It is important to point out that our study is limited to a specific territory and to certain programmes, and therefore generalisations about the results are subject to repeating the study in other geographic areas and for other types of programmes. Moreover, introducing other variables that are not considered in this work could be an important line of future research.

\section{Acknowledgements}

This work has been financed by the Research Project of the Ministry of Science and Innovation, ECO2010-20880, and it has been conducted within the framework of the IMPROVE Group.

\section{References}

Albers, R. (1996). Quality in television from the perspective of the professional programme maker. In S. Ishikawa (Ed.), Quality assessment of television (pp. 101-143). John Libbey Media. Luton, UK.

Andeson, E., Fornell, C., \& Lehmann, D. (1994). Customer satisfaction, market share and profitability: findings from Sweden. Journal of Marketing, 58(3), 53-66. http://dx.doi.org/10.2307/1252310

Andreu, L., \& Bigné, E. (2004). Modelo cognitivo-afectivo de la satisfacción de la en servicios de ocio y turismo. Cuadernos de Economía y Dirección de la Empresa, 21, 85-120.

Aragón, J. A., \& Llorens, F. J. (1996). La calidad en los programas de televisión: estudio empírico sobre sus dimensiones claves y su relación con la satisfacción y la fidelidad de los televidentes. Investigacióny Marketing, 50, 41-48.

Baraybar, A. (2006). Marketing en Televisión. Madrid, Editorial Fragua.

Berné, C., Múgica, J. M., \& Yague, M. J. (1996). La gestión estratégica y los conceptos de calidad percibida, satisfacción del cliente y lealtad. Economía Industrial, 307, 63-74.

Bloemer, J., Ruyter, K., \& Peeters, P. (1998). Investigating drivers of bank royalty: the complex relationship between image, service quality and satisfaction. International Journal of Bank Marketing, 16(7), 276-286. http://dx.doi.org/10.1108/02652329810245984

Blumler, J. G. (1991). In pursuit of programme range and quality. In Quality assessment of broadcast programming. Studies of Broadcasting, 27, 191-206.

Broadcasting Research Unit. (1989). Quality in television: Programmes, program-makers, system. John Libbey and Company, London.

Carvin, D. (1988). Managing Quality: the Strategic and Competitive. New York: Edge Publications.

Casado, M. A. (2005). Nuevas estrategias para el desarrollo del sector audiovisual en las Comunidades Autónomas. Revista Ámbitos, 109-131.

Choi, K. S., Cho, W. H., Lee, S., Lee, H., \& Kim, C. (2002). The relationship among quality, value, satisfaction and behavioural intention in health care provider choice: A South Koream Study. Journal of Business Research, 57, 1-9.

Cronin, J. J., \& Taylor, S. A. (1992). Measuring service quality: a reexamination and extension. Journal of Marketing, 56, 55-68. http://dx.doi.org/10.2307/1252296

Cubelles, X. (2002). Calidad y televisión: consideraciones desde la óptica del mercado. Quaderns del CAC, 14, 27-39.

Del Valle, J. C. (2005). La calidad de la producción audiovisual desde el análisis del valor. Revista Comunicar.

Giese, J. L., \& Cote, J. A. (2000). Defining consumer satisfaction. Academy of Marketing Science Review 1, $1-34$. 
Hair, J., Anderson, R., Tatham, R., \& Black, W. (1999). Análisis Multivariante (5th ed.). Madrid, Prentice Hall, Iberio.

Igartua, J. J., \& Badillo, A. (2003). Audiencias y medios de comunicación. Salamanca: Ediciones Universidad de Salamanca.

Ishikawa, S. (1992). Quality assesment of broadcasting programming research subjetc for the future. Studies on Broadcasting, Theorical Research Center, NHK.

Jacobs, R. D. (1995). Exploring the determinants of cable television subscriber satisfaction. Journal of Broadcasting and Electronic Media, 39(2), 262-274. http://dx.doi.org/10.1080/08838159509364302

Kang, G., \& James, J. (2004). Service quality dimension: an examination of Groonroos's service quality model. Managing Service Quality, 14(4), 266-277. http://dx.doi.org/10.1108/09604520410546806

LaRose, R., \& Atkin, D. (1988). Satisfaction, demographic, and media environment predictors cable subscription. Journal of Broadcasting and Electronic Media, 32(4), $403-413$. http://dx.doi.org/10.1080/08838158809386712

Lu, X., \& Lo, H. (2007). Television audience satisfaction: antecedents and consequences. Journal of Advertising Research, 47(3), 354-363. http://dx.doi.org/10.2501/S0021849907070365

McDougall, G., \& Levesque, T. (2000). Customer satisfaction with services: putting perceived value into the equation. The Journal of Services Marketing, 14(5), http://dx.doi.org/10.1108/08876040010340937

Medina, M. (2006). Calidad y contenidos audiovisuales. Pamplona Editorial Eunsa.

Mepham, J. (1990). The ethics of quality in television. In G. Mulgan (Ed.), The question of quality (pp. 56-72). London: British Film Institute.

Nossiter, T. J. (1986). British television: A mixed economy. In West Yorkshire Media in Politics group: Research on the range and quality of broadcasting services. A report for the Committee on Financing the BBC (pp. 5-76). HMSO. London.

Oliver, R. L. (1980). A cognitive model of antecedents and consequences of satisfaction decisions. Journal of Marketing Research, 17, 460-469. http://dx.doi.org/10.2307/3150499

Palmgreen, P., \& Rayburn II, J. D. (1985). A comparison of gratification models of media satisfaction. Communication Monographs, 52(4), 335-348. http://dx.doi.org/10.1080/03637758509376116

Palmgreen, P., \& Rayburn, J. D. (1979). Uses and gatifications and exposure to public television: a discrepancy approach. Communication Research, 6(2), 155-180. http://dx.doi.org/10.1177/009365027900600203

Papacharissiu, Z., \& Mendelson, A. (2007). An exploratory study of reality appeal: uses and gratifications of reality tv shows. Journal of Broadcasting and Electronic Media, 51(2), 355-370. http://dx.doi.org/10.1080/08838150701307152

Parasuraman, A., Zeithaml, V., \& Berry, L. (1985). A conceptual model of service quality an its implications for future research. Journal of Marketing, 49, 41-50. http://dx.doi.org/10.2307/1251430

Patwardhan, P., Yang, J. Y., \& Patwardhan, H. (2011). Understanding Media Satisfaction: Development and Validation of an Affect Based Scale. Atlantic Journal of Communication, 19(July, 3), 169-188. http://dx.doi.org/10.1080/15456870.2011.584508

Perse, E., \& Ferguson, D. A. (1993). The impact of the newer television technologies on television satisfaction. Journalism Quarterly, 70(4), 843-853. http://dx.doi.org/10.1177/107769909307000410

Perse, E., \& Rubin, A. M. (1988). Audience activity and satisfaction with favourite television soap opera. Journalism Quarterly, 65(1), 368-375. http://dx.doi.org/10.1177/107769908806500216

Rhee, J., Kim, E., \& Shim, M. (2005). Does quality matter in television? - program quality and rating as determinants of television channel brand equity. Paper presented at the annual meeting of the International Communication Association, Sheraton New York, New York City.

Russell, C. A., Norman, A. T., \& Heckler, S. E. (2004). The consumption of television programming: development and validation of the connectedness scale. Journal of Consumer Research, 31(6), 150-161. http://dx.doi.org/10.1086/383431 
Sánchez Tabernero, A. (2006). La medición de la calidad, instrumento de gestión de las empresas audiovisuales. La ética y el derecho en la producción y el consumo del entretenimiento, 59-82.

Shamir, J. (2007). Quality assessment of television programs in Israel: can viewers recognize production value? Journal of Applied Communication Research, 35, 320-341. http://dx.doi.org/10.1080/00909880701434406

Teas, R. (1993). Expectations, performance evaluation and consumer's perceptions of quality. Journal of Marketing, 57(4), 18-34. http://dx.doi.org/10.2307/1252216

Vanhamme, J. (2000). The link between surprise and satisfaction: an exploratory research. Journal of Marketing Management, 16(6), 565-582. http://dx.doi.org/10.1362/026725700785045949

Wonneberger, A., Schoenbach, K., \& Van Meurs, L. (2009). Dynamics of individual viewing behaviour: Models, empirical evidence, and a research program. Communication Studies, 60(3), 235-252. http://dx.doi.org/10.1080/10510970902955992

Zeithaml, V., Berry. L., \& Parasunaman, A. (1993). The nature and determinants of customer expectations of service. Journal of the Academy of Marketing Science, 21, 1-12. http://dx.doi.org/10.1177/0092070393211001

\section{Notes}

Note 1. INFOADEX (2011).

Note 2. Mainly, complete digitalisation of the media, which ended on 3 April 2010, legal changes (General Communications Act) and evolution in the operation of audio-visual content and services.

Note 3. National private and public television stations.

Not e 4. As explained on the Institutional Commission of the Legislative Assembly by the Regional Minister of the Presidency of the Government of Aragón, Javier Velasco.

Note 5. For news programmes, this item was changed for 'it is a very adequate programme for keeping me informed about what is happening in my region'.

Note 6. Compare: The AGFI indicator is far below the desirable minimum of 0.85 , and the RMSEA index is far above the desirable limit of 0.8 (Hair et al., 1999). 